\title{
Interactive comment on "Cross-contamination
} effect on turbulence spectra from Doppler beam swinging wind lidar" by Felix Kelberlau and

\section{Jakob Mann}

\section{Anonymous Referee \#1}

Received and published: 25 November 2019

The comment was uploaded in the form of a supplement:

https://www.wind-energ-sci-discuss.net/wes-2019-71/wes-2019-71-RC1-

supplement.pdf

Interactive comment on Wind Energ. Sci. Discuss., https://doi.org/10.5194/wes-2019-71, 2019. 